\title{
Necrotic sore throat, tender lymphadenopathies, hepatitis and activated lymphocytes in circulating blood as a clinical presentation of severe infectious mononucleosis
}

\author{
Claire Tissot, ${ }^{1}$ Christian Chidiac, ${ }^{1,2,3}$ Florence Ader, $^{1,2,3}$ Tristan Ferry $^{1,2,3}$
}

${ }^{1}$ Service de Maladies Infectieuses et Tropicales, Hôpital de la Croix-Rousse, Hospices Civils de Lyon, Lyon, France

${ }^{2}$ Université Claude Bernard Lyon 1, Lyon, France

${ }^{3}$ Centre International de Recherche en Infectiologie (CIRI), Inserm U1111, CNRS UMR5308, ENS de Lyon, UCBL1, Lyon, France

\section{Correspondence to} Dr Tristan Ferry, tristan.ferry@univ-lyon1.fr

Accepted 2 November 2014
CrossMark

To cite: Tissot $C$, Chidiac $C$, Ader F, et al. BMJ Case Rep Published online: [please include Day Month Year] doi:10.1136/bcr-2014207434

\section{DESCRIPTION}

A previously healthy 21-year-old man presented to the emergency department with odynophagia and cervical lymphadenopathies. Symptoms had started 10 days before with fever and asthenia. Physical examination revealed voluminous and tender cervical lymphadenopathies with an ulcerative and necrotic sore throat (figure 1, panel A) and inspiratory dyspnoea. Splenomegaly and jaundice were noticed. Laboratory findings included lymphocytosis $(5.6 \mathrm{G} / \mathrm{L})$ with $30 \%$ of activated lymphocytes and apoptotic cells (figure 1, panel B and C) and thrombocytopenia $(77 \mathrm{G} / \mathrm{L})$. Liver enzymes were elevated: aspartate aminotransferase $419 \mathrm{U} / \mathrm{L}$ (reference range 15-37), alanine aminotransferase $530 \mathrm{U} / \mathrm{L}$ (15-78); with cholestasis. Epstein Barr virus (EBV) serology was suggestive of primary infection with positive anti-VCA (viral capsid antigen) IgG, positive IgM and negative IgG anti-EBNA (Epstein-Barr nuclear antigen). The patient received acyclovir and corticosteroid to treat this severe infectious mononucleosis (IM). He rapidly recovered.

EBV causes usually subclinical infection during childhood, whereas infection of adolescents and adults results in IM, which is normally a benign illness. ${ }^{1}$ Mild liver enzymes elevation is common (80-90\% of cases) and resolves spontaneously. Symptomatic hepatitis is uncommon (5\% of cases). Fatal liver dysfunction can occur. ${ }^{1}$ Necrotic sore throat is an atypical presentation of IM. Differential diagnoses include Vincent's angina, primary syphilitic lesion, neoplasms and agranulocytosis. ${ }^{2}$ Activated lymphocytes and apoptosis are found in IM but also in HIV, cytomegalovirus infection or toxoplasmosis. Further evidence is needed concerning the therapeutic strategy for patients with severe IM, even if physicians may consider the use of antiviral medication in addition to steroid treatment. ${ }^{3}$

\section{Learning points}

- Necrotic sore throat can be a clinical presentation of severe infectious mononucleosis (IM).

- Acyclovir and corticosteroids may be proposed as an option for patients with severe IM.

Contributors $\mathrm{CT}$ wrote the case report; $\mathrm{CT}$ and TF performed the literature review; CT, TF, CC and FA significantly participated in improvement of the manuscript.

\section{Competing interests None.}

Patient consent Obtained.

Provenance and peer review Not commissioned; externally peer reviewed.

\section{REFERENCES}

1 Vine LJ, Shepherd K, Hunter JG, et al. Characteristics of Epstein-Barr virus hepatitis among patients with jaundice or acute hepatitis. Aliment Pharmacol Ther 2012;36:16-21.

2 Alcaide ML, Bisno AL. Pharyngitis and epiglottitis. Infect Dis Clin North Am 2007;21:449.

3 Rafailidis $\mathrm{Pl}$, Mavros MN, Kapaskelis A, et al. Antiviral treatment for severe EBV infections in apparently immunocompetent patients. J Clin Virol 2010;49:151-7.

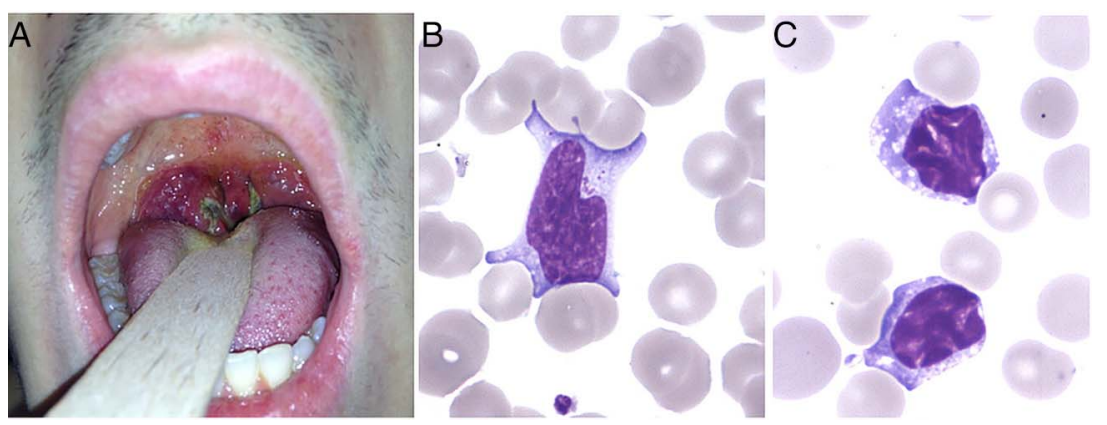

Figure 1 Clinical aspect of the necrotic sore throat (panel A) in a patient presenting severe infectious mononucleosis with cytolysis, activated lymphocytes (panel B) and apoptotic cells (panel C) in circulating blood. 
Copyright 2014 BMJ Publishing Group. All rights reserved. For permission to reuse any of this content visit http://group.bmj.com/group/rights-licensing/permissions.

BMJ Case Report Fellows may re-use this article for personal use and teaching without any further permission.

Become a Fellow of BMJ Case Reports today and you can:

- Submit as many cases as you like

- Enjoy fast sympathetic peer review and rapid publication of accepted articles

- Access all the published articles

- Re-use any of the published material for personal use and teaching without further permission

For information on Institutional Fellowships contact consortiasales@bmjgroup.com

Visit casereports.bmj.com for more articles like this and to become a Fellow 